\title{
CORRESPONDENCE
}

\section{PROBABLE RECOGNITION OF HUMAN ANISAKIASIS IN BRAZIL?}

\section{Dear Sir:}

When making a survey of literature about fish-borne nematodes of human infections in Brazil the authors found a Letter to the Editor of Revista do Instituto de Medicina Tropical de São Paulo by AMATO NETO et al., July 2, $2007^{1}$ about a probable recognition of human anisakiasis in Brazil.

Human infections by several species of nematodes infecting fish, of different genera belonging to more than one family, including the Anisakidae, were reported in several countries, mainly those where raw, lightly cooked or marinated fish are traditionally eaten ${ }^{7}$.

In the above cited Letter to the Editor the infection of three anglers from São Paulo who had travelled to Ilha do Bananal, Tocantins State, Brazil, to fish, was described. From the total of nine people who had travelled to fish, five ate raw fish of the genus (sic) Cichlydae (sic), and these five became sick around fifteen to twenty days after they left the island and returned to São Paulo, and three of them were attended at a medical service. The other four anglers who did not eat raw fish were not sick.

The symptoms of the sick people included eosinophilia, abdominal, epigastric or pain in several parts of the body, and macular rash in the body trunk or in the abdomen. The authors concluded, based on clinic aspects, laboratory alterations and epidemiological circumstances, that the patients' signs and symptoms suggested a case of anisakiasis acquired by ingestion of raw fish. The fact that anglers that did not eat raw fish did not become sick was a strong evidence of the way of acquiring the parasites.

We agree that the anglers were most probably infected with nematodes infecting fish from the Cichlidae family (not the genus Cichlidae!). However, we believe that it is unlikely that the etiological agent was Anisakis sp. or Pseudoterranova sp. The species of both genera are parasites only of marine fish ${ }^{2,5}$, and due to the geographical situation of the Bananal Island at Tocantins River it is virtually impossible to the local fish to be infected by species of those genera once they are far away from the marine habitat. Therefore, they cannot predate the intermediate hosts of those parasites. As far as the authors are aware there is only one reliable description of anisakiasis in Brazil $^{3}$.

As an alternative parasite which might have infected the patients, we believe that Gnathostoma spp. is the most probable species based on the fact that all the patients had eosinophilia, which is characteristic of the infection caused by Gnathostoma, but not usually reported with infection by Anisakis spp. or Pseudoterranova $\mathrm{spp}^{4}$. On the other hand, infection by Gnathostoma spp. usually causes skin lesions which are frequent on the abdomen and back of the body, while these symptoms are rarely observed with Anisakis spp. or Pseudoterranova spp $\mathrm{sp}^{6}$. It is important to note that Gnathostomiasis was reported in a patient who ate raw fish (Cichla sp., Family Cichlidae) captured at Tocantins River, presenting eosinophilia, swelling and reddish nodules on the thorax. Plasma immunoblot allowed the identification of Gnathostoma spinigerum. ${ }^{8}$
We full agree with AMATO NETO et al. when they state that "it is understood that such reports are not deemed important enough to warrant formal register. Many such occurrences are not considered worthy of publication, and as such, delay acquisition of up-to-date information". There are probably much more human infections cases in Brazil by several species of fish nematodes, both marine and freshwater, than generally believed. Any information concerning possible infections and their characteristics are extremely important for a better understanding of the Brazilian situation concerning this biological and medical important question.

Jorge Costa EIRAS Dep. Biologia, Fac. Ciências, Univ. Porto, Porto, Portugal; CIIMAR, Centro Interdisciplinar de Investigação Marinha e Ambiental, Porto, Portugal. Gilberto Cesar PAVANELLI, Mirian Ueda YAMAGUCHI Unicesumar, Programa de pós-graduação em Promoção da Saúde, Bloco 7

Av. Guerner Dias, 1610, Jardim Aclimação, 87050-900 Maringá, PR, Brazil.

Ricardo Massato TAKEMOTO, Letícia Cucolo KARLING UEM. Nupelia, Bloco G90, Av. Colombo 5790, 87020-900 Maringá, PR, Brazil.

Correspondence to: J.C. Eiras, CIIMAR, Centro Interdisciplinar de Investigação Marinha e Ambiental, R. dos Bragas, 4050-123, Porto, Portugal. E-mail: jorge.eiras1@gmail.com

\section{REFERENCES}

1. Amato Neto V, Amato JG, Amato VS. Probable recognition of human anisakiasis in Brazil. Rev Inst Med Trop Sao Paulo. 2007;49:261-2.

2. Audicana MT, Kennedy MW. Anisakis simplex: from obscure infectious worm to inducer of immune hypersensitivity. Clin Microbiol Rev. 2008;21:360-79.

3. Cruz AR, Souto PC, Ferrari CK, Allegretti SM, Arrais-Silva WW. Endoscopic imaging of the first clinical case of anisakidosis in Brazil. Sci Parasitol. 2010;11:97-100.

4. Herman JS, Chiodini PL. Gnathostomiasis, another emerging imported disease. Clin Microbiol Rev. 2009;22:484-92.

5. Lymbery AJ, Cheah FY. Anisakid nematodes and anisakiasis. In: Murrell KD, Fried B, editors. Food-borne parasitic zoonoses: fish and plant-borne parasites. New York: Springer; 2007. p. 185-207.

6. Moore DA, McCroddan J, Dekumyoy P, Chiodini PL. Gnathostomiasis: an emerging imported disease. Emerg Infect Dis. 2003;9:647-50.

7. Murrell KD, Fried B, editors. Food-borne parasitic zoonoses: fish and plant-borne parasites. New York: Springer; 2007

8. Vargas TJ, Kahler S, Dib C, Cavaliere MB, Jeunon-Sousa MA. Autochthonous gnathostomiasis, Brazil. Emerg Infect Dis. 2012;18:2087-9. 